\title{
THE USE OF CONSONANT ELISION BY SRI MULYANI DURING HER INTERVIEW SESSION WITH THE BANKER
}

\author{
Anggi Rizky Firdhani ${ }^{1}$, Lia Maulia Indrayani ${ }^{2}$, Sutiono Mahdi ${ }^{3}$ \\ anggi12001@mail.unpad.ac.id, lia.maulia@unpad.ac.id, sutiono.mahdi@unpad.ac.id
}

\author{
UNIVERSITAS PADJADJARAN
}

\begin{abstract}
This research is entitled "The Use of Consonant Elision by Sri Mulyani During Her Interview Session with The Banker". The objects of this research are the consonant elisions that are produced by Sri Mulyani when she was interviewed by The Banker. The objectives of this research are to describe and analyze the frequency of consonant elision used by Sri Mulyani and to find out the phonemes that are often being elision-ed by Sri Mulyani in her interview with The Banker. The analysis of this research was done by using descriptive qualitative analysis method. This study uses Carr's (2008), Giegerich's (1992), and Roach's (2001) theories about phonological rules and elision. This study shows that during her interview, Sri Mulyani uses consonant elision for 26 times and she tends to do the omission to the phoneme /t/ (19 times), /d/ (5 times), /r/ (1 times), and /s/ ( 1 times).
\end{abstract}

Keywords: Consonant Elision, Elision, Phonology, Phonological Rules, Sri Mulyani

\section{A. INTRODUCTION}

In English pronunciation, there are various ways of pronunciation for each individual. This phenomenon occurs because of numerous factors, such as areas of origin, cultural influences, and social environment. English pronunciation involves the production of each sound and pronunciation of words, phrases, and sentences with correct spelling, emphasis and/or intonation. In addition, there is a way to read the word correctly called phonetic transcription', which is defined as a kind of alphabetic writing in which each letter represents a sound (Fromkin, Rodman, \& Hyams, 2003). The purpose of phonetic transcriptions is to provide clear and unambiguous information to language learners, such as which sounds should be used on a word or phrase, and in what order to use the sound.

The branch of linguistics which studies the sound system of languages is called phonology. The pronunciation of speech sound in English is governed by certain rules, and the rule is called the phonological rules. This statement was approved by Fromkin, Rodman, and Hyams (2003) because, in their book, they state that "phonological rules relate to phonemic representations and phonetic representations of the speaker's knowledge of the language." With the existence of these phonological rules, we cannot pronounce any speech sounds carelessly, especially in pronouncing speech sounds in English. There are several phonological rules that we need to obey in pronouncing English speech sound, such as the use of pressure, intonation, and so forth. The aim of studying the rules of phonology is to give a phonetic information or guideline on how to pronounce a word in a correct way, so 
the meaning that conveyed from the spoken word can be conveyed correctly. Although the specific rules of phonology differ from language to language, the kind of rules, what they do, and the natural classes they refer to are the same cross-linguistically (Fromkin, Rodman, \& Hyams, 2003).

\section{B. LITERATURE REVIEW \\ 1. Elision}

In English pronunciation, sometimes a speaker simplifies the pronunciation of some words. According to Carr (2008), this process of simplification is counted as a part of the phonological rules. In his book, Carr mentions that simplification consists of various types, those are reduction, lenition, assimilation, and elision. Sometimes, the simplification occurs in order to ease the native speakers in expressing their feelings. It is common for them to speak English in high speed along with their emotions, and as the result, they make a 'shortcut' to ease their pronunciation. Sometimes, the native speakers of English make a complete disappearance of one or more sounds in a word or phrase as an attempt to make a word or phrase easier to pronounce, and that phenomenon is called elision (Crystal, 2008). According to Giegerich (1992) in Febriyanti (2015), one of the most common elisions in English is the omission of phoneme /t/ and /d/.

Although the use of elision is often used by native speakers, in fact, native speakers are not the only person who use elision in uttering some words in English. Many non-native speakers often use elision when they are speaking in English, including Indonesians. One example of the native speakers of Indonesian who use elision while speaking in English is the Minister of Finance of the Republic of Indonesia, Sri Mulyani. Sri Mulyani is one of the prominent figures in Indonesia, so it is not surprising that Sri Mulyani is often required to speak English.

Sri Mulyani's speaking style in English caught the attention of the researcher, especially when the researcher watched her being interviewed about the tax amnesty in Indonesia by The Banker, a British financial media, for approximately nine minutes. In the interview, the researcher saw that Sri Mulyani had her own pattern when she tried to speak English and she used a lot of elisions, particularly consonant elision when she was pronouncing certain words. The researcher saw that the use of elision by Sri Mulyani while being interviewed by The Banker is interesting to be examined in this research.

Based on the explanation above, the researcher is interested to find out how often Sri Mulyani used elision while being interviewed and to find out the phonemes that are often being elision-ed by Sri Mulyani in her interview with The Banker.

\section{Types of Simplification}

As the researcher mentioned in the explanation above that in English pronunciation, sometimes, a speaker simplifies the pronunciation of some words. The simplification occurs in order to ease the native speakers in expressing their feelings. It is common for them to speak English in high speed along with their emotions, and as the result, they make a 'shortcut' to get the ease of their pronunciation. According to Carr (2008), this process of simplification is counted as a part of the phonological rules. In his book, Carr mentions that simplification consists of various types, those are reduction, lenition, assimilation, and elision. Elision is going to be the focus of this research. 
Firdhani, Indrayani \& Mahdi: The Use of Consonant...

Crystal (2008) defines that elision is a complete disappearance of one or more sounds in a word or phrase as an attempt to make a word or phrase easier to pronounce. The process of elision occurs when speakers leave or delete a phoneme out of pronunciation as an attempt to fasten and get rid of difficulties in speech. Elision happens with both consonants and vowels. Carr (2008) states that where the cluster of consonants arise through the combination of words into phrases, they are frequently reduced in this way. For example, the phrase crisp bowl is often pronounced as [ $\mathrm{k}^{\mathrm{h}} \mathrm{risbovl}$, with the final stop in crisp elided. Carr also states that vowel elision may result in the loss of an entire syllable as in university when it is pronounced as [ju:.ni'v3:.sti].

According to Giegerich (1992) cited in Febriyanti (2015), elision often happens before sonorant consonants which give the consonants an opportunity to be syllabic so that they will occupy the peak of the syllable. The process is called vowel elision, for examples are button $/ \mathrm{b} \Lambda \mathrm{tən} /$ or $/ \mathrm{b} \Lambda \mathrm{tn} /$ and little $/ 1 \mathrm{itəl} /$ or $/ 1 \mathrm{itl} /$. Giegerich also explains that the most common elision in English words is the omission of sounds /t/ and /d/ at the word boundary: they are positioned at end of a word before going to the next word. For example, the elision of phoneme /t/ in the word postman is missing, so its pronunciation from [poustmən] changed to [pousmon] because of the speed of the speaker's speech. In the case of phoneme $/ \mathrm{t} /$, the preceding consonant must be voiceless; in the case of $/ \mathrm{d} /$, the preceding consonant must be voiced. In both cases, elision happens with any following consonant, except $/ \mathrm{h} /$ and sometimes /j/, e.g. Christmas becomes ['krismos], listen becomes [1isən], left foot becomes [lefo:t], but it doesn't happen in left hand [left hænd], left you [leffo], and old man [ould mæn]. Roach (2001) agreed with that explanation: Roach states the first type of elision that can be found in connected speech involves a loss of weak vowels after $/ \mathrm{p} /, \mathrm{t} / \mathrm{t}$, $/ \mathrm{k} /$. Roach pointed out that the vowel in the first syllable may be omitted. That is, the aspiration of the initial plosive may take up the whole of the middle portion of the syllable as in "potato", "tomato", "canary" "perhaps" and "today"

\section{RESEARCH METHODOLOGY}

The method used in this research is descriptive qualitative analysis method. The descriptive qualitative analysis method is a research method that produces descriptive data in the form of written words or oral things that can be observed (Bogdan and Taylor, 1975). Qualitative descriptive analysis research relates to ideas, perceptions, opinions, and all of them cannot be measured by numbers. This qualitative descriptive study aims to obtain information about existing circumstances (Mardalis, 1999) and is designed to collect information about current ongoing realities (Cevilla, 1993).

In doing this study, the researcher transcribes the audio via video obtained from Youtube. The video that is chosen by the researcher is an interview video between Sri Mulyani and The Banker entitled View from IMF: Interview with Sri Mulyani Indrawati, Finance Minister, Indonesia. To perform the audio transcription, the researcher listened to the speech sounds produced by Sri Mulyani carefully, then the researcher marked the pronunciation of any elision-ed words that are produced by Sri Mulyani. After that, the pronunciation of some words spoken by Sri Mulyani compared with the General American English (GA) pronunciation. 


\section{FINDINGS AND DISCUSSION}

The process of elision involves the omission of a phoneme in its pronunciation. The researcher found several cases which belong to elision in Sri Mulyani's utterance during her interview, and most of them the elision of phoneme /t/ and /d/. In Sri Mulyani's interview with The Banker, which lasted approximately for 9 minutes, the researcher found out that Sri Mulyani used elision 26 times. More detailed information can be seen in the table below.

Table 1.

The frequency of elision uttered by Sri Mulyani during her interview with The Banker

\begin{tabular}{clll}
\hline $\begin{array}{l}\text { Frequency of } \\
\text { the Elision of } \\
\text { Phoneme } / \mathrm{t} /\end{array}$ & $\begin{array}{l}\text { Frequency } \\
\text { of the } \\
\text { Elision of } \\
\text { Phoneme } \\
/ \mathrm{d} /\end{array}$ & $\begin{array}{l}\text { Frequency } \\
\text { of the } \\
\text { Elision of } \\
\text { Phoneme } / \mathrm{r} /\end{array}$ & $\begin{array}{l}\text { Frequency } \\
\text { of the }\end{array}$ \\
$\begin{array}{c}\text { Elision of } \\
\text { Phoneme } \\
\text { /s/ }\end{array}$ \\
\hline TOTAL
\end{tabular}

From the table above, we can see that the phoneme that is often omitted by Sri Mulyani is phoneme $/ \mathrm{t} /$, followed by phoneme $/ \mathrm{d} /, / \mathrm{r} /$, and $/ \mathrm{s} /$. Here is the list of pronunciation realizations by Sri Mulyani that are being elision-ed, compared with General American English Pronunciation (GA).

\section{Table 2.}

List of pronunciation realizations by Sri Mulyani that are being elision-ed

\begin{tabular}{|c|c|c|c|}
\hline No & Word & GA English & Realization by \\
\hline 1. & Months & $\begin{array}{l}\text { Pronunciation } \\
/ \mathrm{m} \wedge \mathrm{n} \theta \mathrm{s} /\end{array}$ & $\begin{array}{l}\text { Sri Mulyani } \\
{[\mathrm{m} \wedge \mathrm{ns}]}\end{array}$ \\
\hline 2. & Month & $/ \mathrm{m} \Lambda \mathrm{n} \theta /$ & {$[\mathrm{m} \wedge \mathrm{n}]$} \\
\hline 3. & Went & /went/ & [wen] \\
\hline 4. & Export & /ek.spo:rt/ & [ekspor] \\
\hline 5. & Import & /Im.po:rt/ & [Impor] \\
\hline 6. & Left & /left/ & [lef] \\
\hline 7. & Lengthen & /ley.Өən/ & [leyhən] \\
\hline 8. & Project & /pra:.dzekt/ & [pra:.dzek] \\
\hline 9. & Affect & /a'fekt/ & [ə' fek] \\
\hline 10. & Past & /pæst/ & [pæs] \\
\hline 11. & Percent & /pə'sent/ & [pə'sen] \\
\hline 12. & Wealth & /welo/ & [welh] \\
\hline 13. & Robust & /rov'b $\Lambda_{\mathrm{st}} /$ & {$\left[\mathrm{rov}^{\prime} \mathrm{b} \Lambda \mathrm{s}\right]$} \\
\hline 14. & Government & 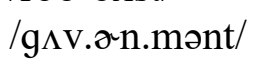 & 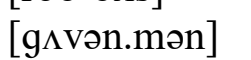 \\
\hline 15. & Department & /di'pa:rt.mont/ & [dipa:rmən] \\
\hline 16. & Important & /Im'po:r.tənt/ & [Importən] \\
\hline 17. & Conduct & /kən'd $\mathrm{k} \mathrm{kt} /$ & [kən'd $\mathrm{d}$ k] \\
\hline 18. & Want & /wa:nt/ & [won] \\
\hline
\end{tabular}


Firdhani, Indrayani \& Mahdi: The Use of Consonant...

\begin{tabular}{|c|c|c|c|}
\hline 19. & Trust & $/ \operatorname{tr} \Lambda \mathrm{st} /$ & {$[\operatorname{tr} \Lambda \mathrm{s}]$} \\
\hline 20 . & Behind & /bi'haind/ & [bi'hain] \\
\hline 21. & Land & /lænd/ & [læn] \\
\hline 22. & Spending & /spen.din/ & [spenin] \\
\hline 23. & Abandoned & /a'bæn.dənd/ & [ə'bæn.dən] \\
\hline 24. & Second & /sek.ənd/ & [sek.ən] \\
\hline 25 . & Course & /ko:rs/ & [kos] \\
\hline 26. & Maintenance & /mein.tən.əns/ & [mein.tən.ən] \\
\hline
\end{tabular}

From the table above, the researcher sees the phonological pattern that is used by Sri Mulyani when she is talking. According to the table, we can see that mostly, the omission of the phoneme /t/ and /d/ was done by Sri Mulyani when she had to utter the sonorant consonantal sounds such as the liquid sounds $(1, r)$ and nasal sounds $(n, m, y)$ that appear before the phoneme $/ \mathrm{t} /$ and $/ \mathrm{d} /$. The phenomena indicate that plosive alveolar sounds such as $/ \mathrm{t} /$ and $/ \mathrm{d} /$ is quite difficult to pronounce when those sounds are placed after the liquid sounds or after the nasal sound. Therefore, the elision occurs as the way of Sri Mulyani in maintaining the speed of her speech in order to make the pronunciation easier.

\section{E. CONCLUSION}

Based on the explanations above, the researcher can conclude that in Sri Mulyani's interview with The Banker, which lasted approximately for 9 minutes, Sri Mulyani used elision for 26 times and most of them are the elision of phoneme /t/ (19 times) and /d/ (5 times). Mostly, the omission of the phoneme / $\mathrm{t} /$ and /d/ was done by Sri Mulyani when she had to utter the sonorant consonantal sounds such as the liquid sounds $(1, r)$ and nasal sounds $(n, m, y)$ that appear before the phoneme $/ \mathrm{t} /$ and $/ \mathrm{d} /$. That phenomena show that plosive alveolar sounds such as $/ \mathrm{t} / \mathrm{and} / \mathrm{d} /$ is quite difficult to pronounce when those sounds are placed after the liquid sounds or after the nasal sound. Therefore, the elision occurs as the way of Sri Mulyani in maintaining the speed of her speech in order to make the pronunciation easier.

\section{F. REFERENCES}

Bogdan, R., \& Taylor, S. (1975). Introduction to Qualitative Research Methods. New York: John Willey and Sons.

Carr, P. (2008). English Phonetics and Phonology: An Introduction. West Sussex:

Blackwell Publishing.

Cevilla, C. G. (1993). Pengantar Metode Penelitian. Jakarta: Universitas Indonesia.

Crystal, D. (2008). A Dictionary of Linguistics and Phonetics. Oxford: Blackwell Publishing.

Febriyanti, D. N. (2015). Assimilation, Reduction and Elision Reflected in the

Selected Song Lyrics of Avenged Sevenfold. Journal of Language and Literature, 14-19.

Fromkin, V., Rodman, R., \& Hyams, N. (2003). An Introduction to Language.

Boston: Thomson/Heinle.

Giegerich, H. (1992). English Phonology: An Introduction. Cambridge:

Cambridge University Press.

Mardalis. (1999). Metode Penelitian Suatu Pendekatan Proposal. Jakarta: Bumi

Aksara. 
ELTIN Journal, Volume 6/II, October 2018

Roach, P. (2001). English Phonetics and Phonology: A Practical Course.

Cambridge: Cambridge University Press. 